\title{
POEMA FEMINISTA
}

\section{FEMINIST POEM}

\author{
Marília Santos ${ }^{1}$
}

\section{RESUMO}

Esse texto é composto por 13 poemas. Esses poemas foram escritos em 2018, como uma maneira de gritar para a sociedade patriarcal que silencia, estupra, enlouquece, machuca e mata nós mulheres. Eles foram escritos para o projeto Corpos Poéticos, em que quatro mulheres (uma negra, uma trans, uma gorda e uma estuprada) foram fotografadas (por Lays Lira), utilizando seus corpos como meio de empoderamento e denúncia. O objetivo do projeto era expor as fotografias com as poesias. Mas este nunca foi colocado em prática. Isso eu conto em um artigo. Aqui, de forma artística, deixo meu grito poético, que é individual e coletivo, singular e plural.

Palavras-chaves: Poesia; Feminismo; Mulher.

\section{ABSTRACT}

This text consists of 13 poems. These poems were written in 2018, as a way of shouting to the patriarchal society that silences, rapes, goes crazy, hurts and kills us women. They were written for the project Corpos Poéticos (Poetic Bodies), in which four women (one black, one trans, one fat and one raped) were photographed (by Lays Lira), using their bodies as a means of empowerment and denunciation. The aim of the project was to expose the photos with the poetry. But this was never put into practice. This I tell in an article. Here, in an artistic way, I leave my poetic shout, which is individual and collective, singular and plural.

Keywords: Poetry; Feminism; Women.

\section{INTRODUÇÃO}

Apresento aqui 13 poemas que escrevi em 2018. Eles foram escritos como uma forma que encontrei de gritar para a sociedade patriarcal que silencia, estupra, enlouquece, machuca e mata (nós) mulheres. Sim, o machismo mata, de várias formas e o tempo todo. Os poemas foram escritos para um projeto, o Corpos Poéticos, realizado junto com a fotógrafa Lays Lira, em que mulheres foram fotografadas, utilizando seus (nossos) corpos como meio de empoderamento e denúncia. O objetivo era expor essas fotografias, junto com os poemas. A sessão de fotos aconteceu. Foram fotografadas quatro mulheres: uma negra, uma trans, uma gorda e uma estuprada (eu). Mas, principalmente por questões financeiras e por falta de

\footnotetext{
${ }^{1}$ Artista. Professora substituta no Departamento de Música da Universidade Federal de Pernambuco (UFPE), Mestra em Música, com área de concentração em Etnomusicologia, pela Universidade Federal da Paraíba (UFPB). Graduada em Música (Magna cum Laude), pela UFPE, e em Letras, pela Faculdade de Filosofia, Ciências e Letras de Caruaru (FAFICA). e-mail: marilia_05030@hotmail.com
} 
Revista

Debates Insubmissos

patrocínios, não conseguimos colocar o projeto em prática. Aqui, de forma artística, deixo meu grito, que é individual e coletivo, singular e plural.

\section{POEMA FEMINISTA (CICLO)}

Não sou flor!

Sou terra, sou ventre.

Não sou flor!

Sou terra, sou ventre.

Não sou flor!

Sou terra, sou ventre.

Sou corpo...

Sou terra, sou ventre.

Não o corpo que querem que eu seja,

Sou terra, sou ventre.

Não um corpo só de carne,

Sou terra, sou ventre.

Com as crias que a mim obrigam,

Sou terra, sou ventre.

Não sou flor!

Sou terra, sou ventre.

Não sou flor!

Sou terra, sou ventre.

Querem-me roubar de mim,

Calar-me com meu sorriso,

Trancar-me no meu próprio corpo...

Rasgam-me por dentro todos os dias.

Obrigam-me a ser uma boneca

Dentro de uma caixa apertada. 
Ensinam-me a fechar as pernas,

Mas querem-nas abertas...

E não falo apenas de metáforas,

Mas de carne.

A mesma carne que é proibida

É dada para os outros,

Menos para mim mesma.

A minha carne...

\section{Os olhares alheios rasgam meu ser}

Numa tentativa de me fazer pequena.

Tão pequena que nem mesmo eu possa me ver.

Os sorrisos pintados em meu rosto

São derretidos pelas lágrimas...

Que me proíbem de chorar.

Minhas feridas mancham a roupa

Que me obrigam a lavar

Para esconder quem me dilacerou.

Meus cortes não estão apenas na pele.

Minha alma está rasgada.

E meu coração ferido.

Mas a força de mim não se foi!

Vou continuar lutando,

Contra o lugar o qual "me deram"

Pelo espaço que é meu,

Pelo meu ventre, meu corpo,

Meu prazer, minhas escolhas,

Minha inteligência, minha liberdade...

Pelo direito de ir e vir

Sem que o medo da morte seja realidade. 


\section{Minha pele foi destroçada}

Com olhares, palavras e escarros.

Disseram que não sou mulher.

Definiram-me como um pedaço de carne.

Sim, uma carne que sem mim nada é.

Eu sou corpo, porque meu corpo sou eu.

Eu sou mulher!

Sou corpo.

O meu corpo é mulher.

\section{De mim querem a autoestima,}

Minha cabeça, baixa.

Roubaram minha beleza, a verdadeira,

E me puseram dentro de um molde

Daquilo que não quero ser.

Sou um corpo reprimido.

Sou um corpo reprimido!

Sou um corpo reprimido?

Não! Esse corpo não posso ser.

\section{Grande é a farsa}

Da hipócrita sociedade.

A mulher que na rua sorrir

É a mesma obrigada a parir

Um filho que não quis ter.

Muitos dedos apontam

Para aquela que trabalha

Que seus sonhos não abandonou

Só porque mãe se tornou. 


\section{Querem-me musa.}

E até sou.

Sou minha própria,

A musa da minha criação.

Porque parindo-me,

De dentro para fora,

E de fora para dentro,

Vou me expandindo,

Espelhando,

Espalhando.

Recriando-me...

\section{A loucura... ah, a loucura...}

Quem me dera fosse ela

Da minha preocupação a causa.

Dos que me tentam oprimir,

Ela é a mais fiel amiga.

Quando grito forte,

Sim! Grito! GRITO! GRIIITO!!!!

Logo me atribuem uma capa.

Um manto de insanidade

Jogam para encobrir

O tapa na cara que me deram,

A face verdadeira do meu ex,

$\mathrm{O}$ estupro do meu marido,

$\mathrm{O}$ gozo na cara que levei.

$\mathrm{O}$ vômito de sangue...

Escondido por trás de um sorriso

Que engulo sem chorar.

Que engulo sem chorar...

Não! Não sou louca,

Muito menos histérica. 
Sou fêmea, sou mulher.

Não a mulher que a sociedade quer.

Sou a mulher que quero ser.

Sou fêmea, sou mulher.

\section{Sou de todas as cores,}

Das cores que quero ser.

Se no caos me colocaram,

Enganaram-se tentando me vencer.

Pois o caos primeiro fui Eu.

$\mathrm{O}$ caos que faz tudo nascer.

Embora criação, sou a criadora.

Sei criar de todas as formas,

Do meu ventre, se eu quiser,

Também do coração.

Mas se não, continuo sendo mulher.

Todos os dias vou criando,

Crio por fora e por dentro,

Até o que ninguém pode ver,

$\mathrm{Eu}$ (re)crio o meu ser.

Quanto mais eu falo,

Mais querem me emudecer.

Então eu grito!!!

Grito alto para que me escutem.

Não querem me ouvir...

Ambicionam-me imóvel, objeto.

Fizeram-me acreditar que sou quebrável.

Oh, grande ironia...

Sou carne, sou sangue, sou vida... 


\section{Disseram-me que eu poderia sonhar,}

Mas um sonho que não é meu.

Meus desejos eram um risco (para quem?),

Por isso a eles eu deveria calar

E a nenhuma outra Eva contar.

Não sabiam que eu era Lilith

E tinha minhas próprias asas.

Então hoje tenho voado

E para todas as Evas contado

Que elas também sabem voar,

Que a vida não é nos sonhos,

Mas no chão no qual se pisa,

Das dores que se sente,

Da alegria que se replica...

Não importa o que lhe dizem, É ela quem tem que escolher,

A maçã ou a romã,

$\mathrm{O}$ fruto que vai comer.

\section{Podem me despedaçar}

Que eu me reconstruo.

Sim! Me reconstruo,

Quantas vezes for preciso.

Ponto por ponto, linha por linha,

Carne por carne, sangue por sangue,

Eu me reconstruo.

Opressão, violência, morte.

Opressão, violência, morte.

Opressão, violência, morte.

Opressão, violência, morte.

Opressão, violência, morte. 
Revista

Debates Insubmissos

Opressão, violência, morte.

Opressão, violência, morte.

Opressão, violência, morte.

Opressão, violência, morte.

Opressão, violência, morte.

Opressão, violência, morte.

Opressão, violência, morte

Opressão, violência, morte.

Silêncio...

Submetido: 08/05/2021

Aprovado: 30/08/2021 